\title{
The effect of some environmental factors on lactation length, milk yield and calving intervals of Anatolian Buffaloes in Bartin province of Turkey
}

\author{
Kürşat Alkoyak ${ }^{1^{*}}$ (๑), Sezer Öz ${ }^{1}$ (D) \\ ${ }^{1}$ Republic of Turkey Ministry of Agriculture and Forestry, General Directorate of Agricultural Research and Policies, \\ Department of Livestock and Aquaculture Research Ankara, Turkey.
}

\section{Article History}

Received: 09 September 2020

Accepted: 10 December 2020

First Online: 25 December 2020

\section{Corresponding Author}

Tel.:+ $903123157623-1255$

E-mail:kursatalkoyak@gmail.com

\section{Keywords}

Anatolian buffalo

Environmental factors

Lactation length

Milk yield

Calving interval

\begin{abstract}
This study aims to determine the environmental factors effected to lactation length (LL), lactation milk yield (LMY), calving intervals (Cl) of Anatolian buffaloes in Bartın. In this study, 1511 milk yield data belonging to 762 Anatolian buffaloes and $957 \mathrm{Cl}$ data belonging to 543 Anatolian buffaloes which has been reared in different environmental conditions between 2015-2019 under the scope of the Anatolian Buffalo Breeding Project being conducted in Bartin province. The least squares method was used for determining the effect of environmental factors, and Tukey multiple comparison tests were used for multiple comparison. Mean and standard deviations relevant to the LL, LMY, and CI were detected as $260.26 \pm$ 1.33 days, $1035.5 \pm 8.21 \mathrm{~kg}$, and $426.35 \pm 2.91$ days, respectively. County, calving year, and season, age, and lactation number's effects on those parameters were investigated. The effect of calving year $(P<0.001)$ county and season $(P<0.01)$ on $\mathrm{LL}$; county, calving year $(P<0.001)$ and calving age $(P<0.05)$ on LMY; lactation number $(P<0.001)$ and calving age $(P<0.01)$ and season $(P<0.05)$ on $\mathrm{Cl}$ were found statistically significant. Meanwhile, a highly significant positive phenotypic correlation was calculated between $\mathrm{LMY}$ and $\mathrm{LL}(r=0.66, P<0.001)$. There are no adequate studies related to the environmental factors influencing lactation length, lactation milk yield, calving intervals of Anatolian buffaloes. Significant environmental factors detected in this study should be considered in selection programs.
\end{abstract}

\section{Introduction}

Buffalo (Bubalus Bubalis) is an extensively reared as a dairy animal and originated from Asia (Borghese, 2010). While the world's buffalo population was 173 million in 2005, it has reached 206.6 million in 2018. The increasing percentage in the world's buffalo population between 2005-2018 is 19.4 (FAO, 2020). Buffaloes have great importance in regards to the amount of milk produced and milk's nutritional composition. Total buffalo milk production in 2018 was 127.7 million tonnes in the world. This amount constitutes around $15 \%$ of total milk production of the world, therefore buffaloes have become the second highest milk producers of the world after dairy cattle (FAO, 2020).
Buffaloes have been reared in Turkey originated from Mediterranean Buffaloes, which are the sub-group of Riverin Buffaloes and named as Anatolian Buffaloes (Cicek et al., 2009). Buffaloes mainly reared at the Northern, Middle, Marmara, Eastern, and South-Eastern Regions of Turkey (Atasever and Erdem, 2008). While Turkey's buffalo population was 105 thousand in 2005, it has reached 184 thousand in 2019 thanks to the National Anatolian Buffalo Breeding Project in Farm Conditions implemented by the Turkish Ministry of Agriculture and Forestry. There are 1.659 buffaloes reared currently in Bartn province located in the Northwest part of Turkey (TUIK, 2020a). Buffaloes being bred in Turkey for milk and meat production. In addition to their resistance against 
diseases and harsh environmental conditions, not only the higher capability of feed efficiency, converting poorquality feedstuffs into high-quality milk and meat, but also lower expenses needed for husbandry compared to dairy cattle could be considered as other main reasons for engaging in buffalo husbandry (Atasever and Erdem, 2008). Buffalo milk is used in order to produce yoghurt, cream, cheese, and ice cream, and it contains $7.92 \%$ fat and $4.09 \%$ protein. Meanwhile, buffalo meat is used for producing salami (Soysal et al., 2015).

According to TUIK (2020b) 79 thousands tonnes of milk and 73 tonnes of meat produced from buffaloes in 2019 in Turkey. To increase the efficiency of dairy buffaloes, factors that influence milk production should be ameliorated. Total milk production of buffaloes; effected by non-genetic parameters such as season, management, and feed quality (Afzal et al., 2007; Pawar et al., 2012) some other parameters like calving interval and age are closely related to efficient milk production (Khosroshahi et al., 2011). LMY and LL are significant parameters for dairy buffaloes (Chaudhry, 1992).

There is not adequate research about the environmental factors which influence LL, LMY, and $\mathrm{Cl}$ of Anatolian Buffaloes. Hence, more studies required to determine the effects of environmental parameters on production of Anatolian Buffaloes. This study aims to examine siginificant environmental factors influencing $L L$, $\mathrm{LMY}$, and $\mathrm{Cl}$ of Anatolian buffaloes.

\section{Materials and Methods}

Animal material of the study comprises of pedigree records of 762 Anatolian buffaloes' milk yield records and 543 calving interval records in Bartin province (410 $38^{\prime} 28^{\prime \prime} \mathrm{N}$ and $32019^{\prime} 59^{\prime \prime} \mathrm{E}$ ) between 2015-2019. In this study, 1511 milk yield records and 957 calving interval records were evaluated and obtained from Anatolian buffaloes that were born between these years. LMY and $\mathrm{Cl}$ records procured from the database named 'Manda Yıldızı'. The data being uploaded by project technical staff hired for The National Anatolian Buffalo Breeding Project which has been coordinated and supported by the General Directorate of Agricultural Research and Policies (Tekerli, 2019).

Buffaloes are milked twice daily, at morning and evening. Milk records are collected each month with a precision scale which is sensitive to $10 \mathrm{~g} / 50 \mathrm{~kg}$. Anatolian buffaloes with at least the 4 months of lactation data were included in the analysis (Koç and Kızılkaya, 2009). The records between $123 \leq L L \leq 404 \mathrm{~d}$ for $L L$ and $300 \leq \mathrm{Cl} \leq 700 \mathrm{~d}$ for $\mathrm{Cl}$ (Soysal et al., 2018) were evaluated in this study. The data of animals leaving the herd before the lactation ended due to diseases, sales, and deaths were not evaluated. Abort and stillbirths were excluded in the calculation of the $\mathrm{Cl}$.

Buffalo husbandry is carried out under extensive conditions plus similar management and nutritional conditions in the region where the research was conducted. Farmers do not usually apply additional feeding to buffalos particularly in the pasture period, but they do additional feeding according to the current feed (straw, alfalfa, silage, etc.) in winter. On the days when seasonal conditions are suitable for grazing in the region, buffaloes are taken to pasture after morning milking. While most of the farmers are milking by hand, fewer are milking with a machine. This study was conducted in 4 counties; (1) Amasra, (2) Kurucaşile, (3) Center and (4) Ulus. Calving year was grouped between 2015 to 2019. Based on the geo-climatic conditions prevailing in Turkey, calving seasons allocated into four groups; (1) winter (December, January and February), (2) spring (March, April and May), (3) summer (June, July and August) and (4) autumn (September, October and November). Age was divided into five groups: (1) 3-4 yrs, (2) 5-6 yrs, (3) 7-8 yrs, (4) 9-10 yrs, (5) 11 yrs and older. Lactation number was listed numerically one through five.

Among the environmental factors examined in this study, the effect share of the county, calving year, season, age, and lactation number on LL, $\mathrm{LMY}, \mathrm{Cl}$ and were determined using the least squares method. The test of significance in terms of statistics were made by variance analysis and the differences between the averages were evaluated by the Tukey multiple comparison tests. Besides, a phenotypic correlation was calculated from unadjusted data via Pearson Method. The GLM (General Linear Model) procedure in the "Minitab-Version 18" program package was used for statistical analysis of the data (Minitab, 2017)

The effects of various environmental factors on lactation length, lactation milk yield, and calving interval were examined using the model below.

$Y_{i j k m n}=\mu+C_{i}+Y_{j}+S_{k}+A_{i}+L_{m}+e_{i j k l m n} \quad$ as follows;

$Y_{i j k l m n}:$ The yield characteristics of any buffalo (i: county, j: year, k: season, l: age, m: Lactation number)

$\mu$ : Overall (expected) average,

$C_{i:}$ The effect of County ( $\left.i=1,2,3,4\right)$,

$Y_{i}$ : The effect of Calving Year $(j=2015,2016,2017$, 2018, 2019),

$\mathrm{S}_{\mathrm{k}}$ : The effect of Calving Season $(\mathrm{k}=1,2,3,4)$,

$A_{1}:$ The effect of Calving Age $(l=1,2,3,4,5)$

$L_{m}:$ The effect of Lactation Number $(m=1,2,3,4,5)$,

$\mathrm{e}_{\mathrm{ijk} k \mathrm{mn}}$ : Random error which is assumed to be normally independently distributed with zero mean and constant variance (NID, 0, $\sigma 2$ ). 


\section{Results}

In this study, LL, LMY, Cl overall mean and standard error were determined as $260.26 \pm 1.33$ days, $1035.5 \pm$ $8.21 \mathrm{~kg}$, and $426.35 \pm 2.91$ days, respectively (Table 1 ).
The effects of some environmental factors on LL, LMY, and $\mathrm{Cl}$ in Anatolian buffaloes are examined and the mean, standard errors, and effective factors of these characteristics are given in Table 2.

Table 1. Descriptive statistics for LL, LMY, and $\mathrm{Cl}$ in Anatolian buffaloes

\begin{tabular}{|c|c|c|c|c|c|}
\hline Number of Animals & Number of Records & Mean & Standard Error (S) & Minimum & Maximum \\
\hline \multicolumn{6}{|c|}{ Lactation Length (days) } \\
\hline 762 & 1511 & 260.26 & 1.33 & 123 & 404 \\
\hline \multicolumn{6}{|c|}{ Lactation Milk Yield (kg) } \\
\hline 762 & 1511 & 1035.5 & 8.21 & 294.9 & 1986.6 \\
\hline \multicolumn{6}{|c|}{ Calving Interval (days) } \\
\hline 543 & 957 & 426.35 & 2.91 & 300 & 700 \\
\hline
\end{tabular}

Table 2. Least squares means ( $\pm \mathrm{SE}$ ) of lactation number, $\mathrm{LMY}$, and $\mathrm{Cl}$ according to the county, calving year, season, and age, lactation number of Anatolian buffaloes

\begin{tabular}{|c|c|c|c|c|c|c|c|}
\hline \multirow{2}{*}{ Factors } & & \multicolumn{2}{|c|}{ Lactation Length (days) } & \multicolumn{2}{|c|}{ Lactation Milk Yield (kg) } & \multicolumn{2}{|c|}{ Calving Interval (days) } \\
\hline & & $\mathbf{n}$ & (Mean \pm SE) & $\mathbf{n}$ & (Mean \pm SE) & $\mathbf{n}$ & (Mean \pm SE) \\
\hline \multirow{5}{*}{ County } & $P$ & & $* *$ & & $* * *$ & & NS \\
\hline & Amasra & 73 & $278.34 \pm 6.05^{a}$ & 73 & $1145.0 \pm 32.0^{\mathrm{a}}$ & 55 & $399.0 \pm 12.5$ \\
\hline & Kurucaşile & 65 & $246.97 \pm 6.52^{\mathrm{b}}$ & 65 & $1045.4 \pm 34.5^{\mathrm{ab}}$ & 33 & $397.9 \pm 15.9$ \\
\hline & Center & 1201 & $257.66 \pm 2.11^{\mathrm{b}}$ & 1201 & $1026.4 \pm 11.2^{\mathrm{b}}$ & 767 & $402.45 \pm 5.34$ \\
\hline & Ulus & 172 & $255.72 \pm 4.16^{b}$ & 172 & $1100.3 \pm 22.0^{\mathrm{a}}$ & 102 & $395.39 \pm 9.46$ \\
\hline \multirow{6}{*}{ Calving Year } & $P$ & & $* * *$ & & $* * *$ & & $* * *$ \\
\hline & 2015 & 236 & $263.66 \pm 4.59^{\mathrm{ab}}$ & 236 & $870.6 \pm 24.3^{d}$ & 98 & $363.10 \pm 12.2^{\mathrm{d}}$ \\
\hline & 2016 & 309 & $258.40 \pm 4.04^{b}$ & 309 & $973.4 \pm 21.4^{c}$ & 195 & $383.45 \pm 9.41^{c d}$ \\
\hline & 2017 & 425 & $268.26 \pm 3.61^{\mathrm{ab}}$ & 425 & $1182.8 \pm 19.1^{b}$ & 263 & $397.30 \pm 8.25^{b c}$ \\
\hline & 2018 & 431 & $272.21 \pm 3.23^{a}$ & 431 & $1251.2 \pm 17.1^{\mathrm{a}}$ & 326 & $425.91 \pm 6.95^{\mathrm{a}}$ \\
\hline & 2019 & 110 & $235.82 \pm 5.23^{c}$ & 110 & $1118.4 \pm 27.7^{b}$ & 75 & $423.50 \pm 11.1^{\mathrm{ab}}$ \\
\hline \multirow{5}{*}{ Calving Season } & $P$ & & $* *$ & & NS & & $*$ \\
\hline & Winter & 221 & $265.35 \pm 4.09^{a}$ & 221 & $1113.4 \pm 21.6$ & 137 & $418.04 \pm 9.34^{a}$ \\
\hline & Spring & 398 & $261.61 \pm 3.59^{a}$ & 398 & $1072.7 \pm 19.0$ & 230 & $390.28 \pm 8.57^{b}$ \\
\hline & Summer & 523 & $251.68 \pm 3.29^{b}$ & 523 & $1058.7 \pm 17.4$ & 333 & $390.62 \pm 7.50^{\mathrm{b}}$ \\
\hline & Autumn & 369 & $260.05 \pm 3.69^{\mathrm{ab}}$ & 369 & $1072.4 \pm 19.6$ & 257 & $395.71 \pm 8.32^{\mathrm{ab}}$ \\
\hline \multirow{6}{*}{ Calving Age (year) } & $P$ & & NS & & * & & $* *$ \\
\hline & $3-4$ & 348 & $259.88 \pm 5.19$ & 348 & $1020.3 \pm 27.5^{b}$ & 51 & $357.0 \pm 15.1^{c}$ \\
\hline & $5-6$ & 531 & $256.13 \pm 3.90$ & 531 & $1054.8 \pm 20.6^{b}$ & 333 & $388.36 \pm 8.71^{b c}$ \\
\hline & $7-8$ & 338 & $258.47 \pm 3.79$ & 338 & $1072.6 \pm 20.0^{\mathrm{ab}}$ & 298 & $405.52 \pm 7.69^{a b}$ \\
\hline & $9-10$ & 200 & $268.09 \pm 4.47$ & 200 & $1140.9 \pm 23.6^{a}$ & 183 & $408.72 \pm 8.35^{\mathrm{ab}}$ \\
\hline & $11 \leq$ & 94 & $255.79 \pm 6.46$ & 94 & $1107.8 \pm 34.2^{\mathrm{ab}}$ & 92 & $433.70 \pm 11.5^{a}$ \\
\hline \multirow{6}{*}{ Lactation Number } & $P$ & & NS & & NS & & $* * *$ \\
\hline & $1^{\text {st }}$ & 470 & $258.21 \pm 4.54$ & 470 & $1022.1 \pm 24.0$ & 374 & $452.97 \pm 7.84^{\mathrm{a}}$ \\
\hline & $2^{\text {nd }}$ & 420 & $259.93 \pm 3.94$ & 420 & $1068.2 \pm 20.9$ & 322 & $422.79 \pm 7.91^{b}$ \\
\hline & $3^{\text {rd }}$ & 352 & $258.73 \pm 3.93$ & 352 & $1092.3 \pm 20.8$ & 204 & $381.97 \pm 9.39^{c}$ \\
\hline & $4^{\text {th }}$ & 211 & $260.76 \pm 4.76$ & 211 & $1103.4 \pm 25.2$ & 57 & $336.90 \pm 13.9^{d}$ \\
\hline & $5^{\text {th }}$ & 58 & $260.72 \pm 7.54$ & 58 & $1110.5 \pm 39.9$ & - & - \\
\hline
\end{tabular}

* : $\mathrm{P}<0.05 \quad * *: \mathrm{P}<0.01 \quad * * *: \mathrm{P}<0.001 \quad$ NS $:$ Non-Significant $(\mathrm{P}>0.05)$

$a, b, c, d \quad$ : Means in a column with different superscripts differ significantly $(P<0.05)$. 
The effects of the county, calving year, season, calving age, and lactation number on these characteristics were determined. The effect of calving year $(P<0.001)$ county and season $(\mathrm{P}<0.01)$ on LL; the effect of calving age $(P<0.05)$ on LMY was found important, and the effect of calving year and the county on calving age was considered significantly important $(P<0.001)$. While the effects of calving season on $\mathrm{Cl}(\mathrm{P}<0.05)$ and calving age
$(P<0.01)$ were found statistically significant, the effects of calving year and lactation number on $\mathrm{Cl}$ were found to be significant $(P<0.001)$. The high positive phenotypic correlation was calculated between LMY and LL ( $r$ $=0.66, \mathrm{P}<0.001)$. In addition, low positive phenotypic correlations were calculated between $\mathrm{Cl}$ and $\mathrm{LL}(\mathrm{r}=0.15$, $\mathrm{P}<0.001)$ and between $\mathrm{Cl}$ and $\mathrm{LMY}(\mathrm{r}=0.13, \mathrm{P}<0.001)$ (Table 3).

Table 3. Phenotypic correlation ( $\mathrm{rP}$ ) for some traits of Anatolian buffaloes

\begin{tabular}{lccc}
\hline Traits & Lactation Length & Lactation Milk Yield & Calving Interval \\
\hline Lactation Length & - & & \\
Lactation Milk Yield & $0,66^{* * *}$ & - & - \\
Calving Interval & $0,15^{* * *}$ & $0,13^{* * *}$ & - \\
\hline
\end{tabular}

$* * * \quad: \mathrm{P}<0.001$

\section{Discussion}

The LL obtained ( $260.26 \pm 1.33$ days) (Table 1$)$ in this study is longer than the lengths found in Şahin and Ulutaş (2014) (146.6 days), Tekerli et al. (2016) (229.4 days), Uğurlu et al. (2016) (231.9 days), and Koçak et al. (2019) (245.4 days) studies on Anatolian buffaloes. The reason for this case could be taken into account under the following conditions, farmers would like to obtain maximum milk from buffaloes as long as possible, ignoring the economy of lifelong milk production (Hussain et al., 2006). The LL found in the study was relatively short but similar to Rosati and Van Vleck (2002) (270 days) findings in Italian buffaloes, Afzal et al. (2007) (273.3 days) in Nili Ravi buffaloes in Pakistan. However, the LL obtained at the end of this study is shorter than the values reported by Cady et al. (1983) (282 days) and Chaudhry (1992) (302 days) as a result of some researches on Nili Ravi buffaloes. The differences in LL values might be due to various management and feeding programs implemented in the farms.

The effect of county on LL was found significant $(\mathrm{P}<0.01)$ in this study in accordance with Soysal et al. (2018) findings carried out a study on Anatolian buffaloes reared in İstanbul. The highest LL was calculated in Amasra, the lowest was in Kurucaşile. The effect of calving year on $L L$ was determined significant $(P<0.001)$ in this study (Table 2) compatible with the studies carried out by Charlini and Sinniah (2015) from Sri Lanka and Koçak et al.(2019) on Anatolian buffaloes. In this study, the longest LL was obtained in 2018, while the shortest LL was achieved in 2019. Alterations in LL during various calving years may be due to climate factors and/or differences in management practices at the farm. The effect of calving season on $L L$ was found significant $(P<0.01)$ in this study (Table 2) similar to the studies conducted by Hussain et al. (2006) on Nili Ravi buffaloes, Şahin and Ulutaş (2014), and Koçak et al. (2019) on Anatolian buffaloes. Besides, Bashir et al. (2015) also reported that the LL was affected by the calving season. Nevertheless, the abovementioned effect was found non-significant in some studies (Ghaffar et al., 1991; Chaudhry , 1992; Khan and Chaudhry, 2000; Afzal et al., 2007) conducted on buffaloes, in contrast with the findings obtained in this study.

It was observed that Anatolian buffaloes calved in winter have longer LL than calved in summer and autumn as compared with spring (Table 2). Furthermore, the longest LL was achieved in buffaloes calved in winter, while the shortest LL was achieved in buffaloes calved in summer. Similar results were reported by Şahin and Ulutaş (2014) in a study conducted on Anatolian buffaloes in Tokat province of Turkey, contrary to the Khalil et al. (1992) 's findings are relevant to the longest LL in buffaloes calved in spring as a result of a study on Egyptian buffaloes. While some researchers reported that the effect of year, season, and age on LL is significant (Hussain et al., 2006; Marai et al., 2009; Koçak et al., 2019), in this study only the effect of age was found non-significant $(P>0.05)$ apart from other factors. Moreover, Soysal et al. (2018) reported similar results that the effect of age on $\mathrm{LL}$ was not considerable as a result of various studies on Anatolian buffaloes, unlike Khan and Chaudhry (2000)'s reports with respect to the significant effect of calving age on LL.

As a result of this study, no differences were observed $(P>0.05)$ in Anatolian buffaloes in terms of the effect of lactation number on LL. Similar results were obtained by Afzal et al. (2007) in consequence of a study carried out Nili-Ravi buffaloes in Pakistan. However, the effect of lactation number on LL was found significant in most studies conducted on buffaloes. These differences 
might be shown up due to various farm management conditions and various locations of farms. As can be understood from this research (Table 2), as lactation number increases, LL values increase properly even though they are not very dissimilar. Nevertheless, Cady et al. (1983) reported that as lactation number increases, LL values reduce.

The LMY $(1035.5 \pm 8.21 \mathrm{~kg}$ ) (Table 1) obtained in this study is higher than Tekerli et al. (2001) $(894.3 \mathrm{~kg})$, Şahin and Ulutaş (2014) (657.7-761.4 kg) and Uğurlu et al. (2016) $(925.4 \mathrm{~kg})$ reported. On the other hand, it is similar to the value reported as $1000.7 \mathrm{~kg}$ in the study conducted by Tekerli et al. (2016) on different originated Anatolian buffaloes. However, this value found in the study is less than the LMY reported by many other researchers. According to some researches carried out on various buffalo breeds from various countries, LMY reported as; Cady et al. (1983) (1883 kg), Khan and Chaudhry (2000) $(1984 \mathrm{~kg})$ at Nili Ravi buffaloes reared in Pakistan and Rosati and Van Vleck (2002) reported $2286 \mathrm{~kg}$ at Mediterranean buffaloes reared in Italy. These production levels are considerably higher than the milk yield of Anatolian Buffaloes reared in Turkey. Likewise, the milk yield value found in this study is lower than the value obtained by Şekerden (2011) (1300 L) as a result of the study carried out on Anatolian buffaloes in Turkey. These differences in milk yield may result from differences in nutritional and management practices (Charlini and Sinniah, 2015).

The effect of county on LMY was found significant $(P<0.001)$ in this study. Soysal et al. (2018) was found the effect of region significant in their study on Anatolian buffaloes in istanbul, which is consistent with this study. The highest LMY was calculated in Amasra, while the lowest in Central County. These results suggest that Amasra is a suitable region for buffalo breeding. The effect of the calving season on LMY found non-significant $(P>0.05)$ in this study. It was observed that buffaloes that calved during winter and autumn seasons possess more milk production than calved at the other seasons (Table 2). Soysal et al. (2018) found the effect of season on LMY was important contrary to these findings. However, they reported the highest milk yield from buffaloes calved during the autumn and winter seasons as well. Similarly, Catillo et al. (2002) have determined the highest LMY at buffaloes calved in winter and lowest in summer. Şahin and Ulutaş (2014) stated that the main reasons for lower milk yields in summer are temperature stress, the vegetation of pastures, and difficulties at feed supply. On the other hand, the low LL of buffaloes that calved in summer in this study may have caused LMY to be lower than other seasons.

Buffaloes are influenced by different air temperatures in different seasons. They stay longer in barn in the winter, therefore milking for a longer time by feeding inside could provide an opportunity to obtain higher milk yield from buffaloes calved during winter. The region where the research is conducted comprises generally family-type traditional farms. Produced buffalo milk is sold in local markets either as raw milk or by converting it into various dairy products (usually buffalo yoghourt) can thus contribute substantially to the family economy. Considering all these factors, a high level of LMY of buffaloes that are reared in intensive conditions during the winter is an indication of given importance to buffaloes in this period in terms of care and nutrition. Similarly to these findings, Kul et al. (2016) in Anatolian buffaloes and Ghaffar et al. (1991) in Nili-Ravi buffaloes reported that calving season had no significant effect on milk production. Afzal et al. (2007) stated that climate stress factors can be minimized and overcome through better nutrition and management.

The effect of calving year $(P<0.001)$ and age $(P$ $<0.05$ ) on LMY were found significant in the study. The highest milk yield was reached in 2018, while the lowest milk yield was achieved in 2015 (Table 2). The alteration in milk yield observed in different years reflected the level of management and environmental impacts at the farm. The level of management varies according to the skills of farmers, cultivating and rearing system, selection method, and density (Khan, 1986). Catillo et al. (2002), Şahin and Ulutaş (2014) findings confirmed the noticeable effect of calving age on LMY. In this study, the highest LMY determined from buffaloes calved at 9-10 years of age and lowest LMY at 3-4 years of age. It was observed that LMY gradually increased after the age of calved at the age of 9-10 and decreased after the age of $11 \leq$ Similar results obtained by Koçak et al. (2019) the highest milk yield at the age of 9 , and the lowest reported at $\leq 4$. Bashir et al. (2015) emphasized that age may be a more precise factor to be included in models to be utilized in lactation milk yield. Since the culling of buffaloes with lower milk yield from the herd and the expansion of this process contribute to obtaining better LMY than the herd in subsequent lactations (Khan et al., 1997).

The effect of lactation number on LMY was found statistically non-significant $(P>0.05)$, similar to Pawar et al. (2012)'s findings. On the contrary, Afzal et al. (2007) reported that the effect of lactation number on LMY was found statistically significant. Lowest LMY was obtained at $1^{\text {th }}$, while the highest was achieved at $4^{\text {th }}$ and $5^{\text {th }}$. lactations confirming Marai et al. (2009)'s findings related to reaching highest LMY at $4^{\text {th }}$ and $5^{\text {th }}$ lactation number. Furthermore, Afzal et al. (2007) and Khosroshahi et al. (2011)'s findings have promoted these results by their reports for obtaining the lowest LMY at 1 . lactation. It 
was observed that in this study, as lactation number increased, LMY increased regularly (Table 2 ). This increased milk production in subsequent lactations can be explained by the continuation and maturation of the mammary gland.

The average $\mathrm{Cl}$ value for Anatolian buffaloes (426.35 \pm 2.91 days) (Table 1 ) was determined higher than the values found in the studies by Marai et al. (2009) (402.6 day) on Egyptian buffaloes and Soysal et al. (2018) (417 days) on Anatolian buffaloes. Although $\mathrm{Cl}$ was relatively high in the study conducted by Tekerli et al. (2001) they found as 441.9 days similar to this study. On the other hand, from India conducted by Hussain et al. (2006) (473.7 days) on Nili-Ravi buffaloes, Charlini and Sinniah (2015) (470 days) from Sri Lanka, and Koçak et al. (2019) (450.3 days) on Anatolian Buffaloes obtained higher $\mathrm{Cl}$ values than this study.

The effect of county on $\mathrm{Cl}$ was found non-significant ( $P>0.05$ ) in this study similar to Soysal et al. (2018)'s findings. The highest $\mathrm{Cl}$ was observed in Central County, while the lowest in Ulus county. This result shows that the buffalo breeders in Ulus county are more meticulous in reproductive traits and estrus monitoring. $\mathrm{Cl}$ value was linearly decreased, as lactation number increased, coherently with Cady et al. (1983) and Charlini and Sinniah (2015)'s findings. The effect of calving season on $\mathrm{Cl}$ was found statistically significant $(\mathrm{P}<0.05)$, similar to the Tekerli et al. (2001) and Koçak et al. (2019)'s findings at Anatolian buffaloes and Marai et al. (2009)'s findings at Egyptian buffaloes. On the other hand, Soysal et al. (2018) found the effect of calving season on $\mathrm{Cl}$ was non-significant. In the study, the longest $\mathrm{Cl}$ value was observed in Anatolian buffaloes calved in winter, while the shortest value was observed in buffaloes calved in winter. Bashir et al. (2015) and Koçak et al. (2019) support that results by finding the longest $\mathrm{Cl}$ value in buffaloes that calved in winter, the shortest $\mathrm{Cl}$ in buffaloes that calved in summer. The shortest $\mathrm{Cl}$ obtained from the buffalo calved in summer can be explained by the occurrence of postpartum estrus and conception period in the winter. The reduction at daylight and air temperature in winter and autumn seasons may increase the reproductive activity in the buffaloes. As a matter of fact, Hafez (1955) reported that sexual activity was observed in some buffaloes at the onset of autumn. Likewise, Soysal et al. (2018) detected that the effect of calving year, calving age, and lactation number on $\mathrm{Cl}$ was significant in a study conducted in Anatolian buffaloes. Similar results were reported by some researchers (Hussain et al., 2006; Marai et al., 2009; Charlini and Sinniah, 2015) as the effect of lactation number on $\mathrm{Cl}$ was significant. On the contrary, Tekerli et al. (2001) reported that the effect of lactation number and age on $\mathrm{Cl}$ was not signifi- cant in Anatolian buffaloes. In this study, it was observed that with the increase of calving age, the duration of $\mathrm{Cl}$ increased. From this, it can be concluded that $\mathrm{Cl}$ is prolonged as a result of the fact that buffaloes cannot conceive regularly due to reasons such as farm management and abduction of the oestrus cycle.

It was determined that the positive phenotype correlation between LMY and LL is high and siginificant (Table 3). Similar to this study, many researchers reported that the correlations between LMY and LL are high and significant in buffaloes (Khan et al.1997; Afzal et al. 2007; Galsar et al. 2016; Rathod et al. 2018). Phenotypic correlation between $\mathrm{Cl}$ and $\mathrm{LL}$ and between $\mathrm{Cl}$ and $\mathrm{LMY}$ was found significant, positive and very low (Table 3). Rathod et al. (2018) and Jakhar et al. (2016) reported that the phenotypic correlation between $\mathrm{Cl}$ and $\mathrm{LL}$ is significant and positive, similar to this study. However, unlike this study, the correlation coefficient was found to be high in the same study. Similar to this study, Rathod et al. (2018) found a positive and low relationship between $\mathrm{Cl}$ and LMY. On the other hand, Jakhar et al. (2016) reported that there is a significant, low and negative relationship between $\mathrm{Cl}$ and $\mathrm{LMY}$.

\section{Conclusion}

Taking measures to ameliorate maintenance, feeding, and herd management will improve the current situation of the farms and contribute to productivity, in the buffalo farms in Bartin. Among the environmental factors examined in the research; the effects of the county, calving year and age on milk yields, and calving year, season, age, and parity on $\mathrm{Cl}$ were found to be significant. Stud selection and breeding studies can be done considering these important environmental factors in order to improve milk yield and other performances of buffaloes. Also, calving can be planned according to the winter since milk yield found highest in the buffaloes that calved in the winter.

\section{Acknowledgments}

The authors would like to express their most sincere thanks for their contribution to the Directorate General of Agricultural Research and Policies of the Ministry of Agriculture and Forestry and the Provincial Buffalo Breeders Association of Bartin and the Project Technical Staff, which enabled the execution of this study.

\section{References}

Afzal, M., Anwar, M., \& Mirza, M. A. (2007). Some factors affecting milk yield and lactation length in Nili Ravi buffaloes. Pakistan Veterinary Journal 27(3):113-117. 
Atasever, S., \& Erdem, H. (2008). Water buffalo raising and its future in Turkey. The Journal of Agricultural Faculty of Ondokuz Mayıs University 23(1):59-64.

Bashir, M. K., Khan, M. S., Lateef, M., Mustafa, M. I., Khalid, M. F., Rehman, S., \& Farooq, U. (2015). Environmental factors affecting productive traits and their trends in Nili-Ravi buffaloes. Pakistan Journal of life and Social Sciences 1-8.

Borghese, A. (2010). Development and perspective of Buffalo and Buffalo market in Europe and near east. Revista Veterinaria v.21(sup.), p.20-31.

Cady, R. A., Shah, S. K., Schermerhorn, E. C., \& McDowell, R. E. (1983). Factors affecting performance of Nili-Ravi buffaloes in Pakistan. Journal of Dairy Science 66(3): 578-586.

Catillo, G., Macciotta N. P. P., Carretta, A., \& Capplo-Borllinot, A. (2002). Effects of age and calving season on lactation curves of milk production traits in Italian water buffaloes. Journal of Dairy Science 85:1298-1306.

Charlini, B. C., \& Sinniah, J. (2015). Performance of Murrah, Surti,Nili-Ravi buffaloes and their crosses in the intermediate zone of Sri Lanka. Livestock Research for Rural Development 27(3):47

Chaudhry, M. A. (1992). Factors affecting the lactation length and milk yield in Nili-Ravi buffaloes. Asian-Australasian Journal of Animal Sciences 5(2):375-382.

Cicek, H., Gunlu, A., \& Tandogan, M. (2009). Production function analysis of buffalo fattening enterprises in Afyonkarahisar Region of Turkey. Journal of Animal and Veterinary Advances 8(11):2158-2163.

FAO. (2020). Food and Agricultural Organization of the United Nations. (2020) Available in: http://www.fao.org/faostat/ en/\#data/QA. Accessed on 22 June 2020.

Galsar, N. S., Shah, R. R., Gupta, J. P., Pandey, D. P., Prajapati, K. B., \& Patel, J. B. (2016). Genetic estimates of reproduction and production traits in Mehsana buffalo. Indian Journal of Dairy Science. 69(6): 698-701.

Ghaffar, A., Khan, M. I., Mirza, M. A., \& Pirzada, W. H. (1991). Effect of year and calving season on some traits of economic importance in Nili-Ravi buffaloes. Pakistan Journal of Agricultural Research 12:217-221.

Hafez, E. S. E. (1955). Puberty in the buffalo-cow. The Journal of Agricultural Science 46:137-142 (Anita. Breed. Abst. 23: 1670).

Hussain, Z., Javed, K., Hussain, S. M. I., \& Kiyani, G. S. (2006). Some environmental effects on productive performance of Nili-Ravi buffaloes in Azad Kashmir. Journal of Animal and Plant Sciences 16(3-4):66-69.

Jakhar, V., Vinayak, A. K., \& Singh, K. P. (2016). Genetic evaluation of performance attributes in Murrah buffaloes. Haryana Veterinarian 55(1): 66-69.

Khalil, M. H., Afifi, E. A., Bedeir, L. H., \& Zeidan, S. M. (1992). Genetic analysis of lactation traits in Egyptian buffaloes. Egyptian Journal of Animal Production 29:155-172.

Khan, M. A. (1986). Genetic analysis of a purebred herd of Nili-Ravi buffaloes. Ph.D Thesis, University of Agriculture, Faisalabad (Pakistan).

Khan, M. S., Shook, G. E., Asghar, A. A., Chaudhary, M. A., \& McDowell, R. E. (1997). Genetic parameters of milk yield and ad- justment for age at calving in Nili-Ravi buffaloes. Asian Australasian Journal Animal Science 10:505-509.

Khan, M. S., \& Chaudhry, H. Z. (2000). Lactation length and its behavior in Nili-Ravi Buffaloes. Pakistan Veterinary Journal 20 (2).

Khosroshahi, Z. T., Rafat, S. A., \& Shoja, D. (2011). Effects of nongenetic factors in milk production and composition in East Azarbaijan native buffaloes of Iran. Buffalo Bulletin 30(3):202209.

Koç, A., \& Kızılkaya ,K. (2009). Factors influencing test day milk yield of Holstein-Friesian Cows. Animal Production 50(1): 2430.

Koçak, S., Tekerli, M., Çelikeloğlu, K., Erdoğan, M., Bozkurt, Z., \& Hacan, Ö. (2019). An investigation on yield and composition of milk, calving interval and repeatabilities in riverine buffaloes of Anatolia. The Journal of Animal \& Plant Sciences 29(3): 650-656.

Kul, E., Şahin, A., Çayıroglu, H., Filik, G., Uğurlutepe, E., \& Öz, S. (2016). Effects of Calving Age and Season on Some Milk Yield Traits in Anatolian Buffaloes. Scientific Papers Series D, Animal Science Vol. LIX: 33-37.

Marai, I. F. M., Daader, A. H., Soliman, A. M., \& El-Menshawy, S. M. S. (2009). Non-genetic factors affecting growth and reproduction traits of buffaloes under dry management housing (in sub-tropical environment) in Egypt. Livestock Research for Rural Development 21 (3)

Minitab. (2017). Minitab statistical software version 18.1.

Pawar, H. N., Ravi Kumar, G. V. P. P. S., \& Raman Narang, R. (2012). Effect of year, season and parity on milk production traits in Murrah buffaloes. Journal of Buffalo Science 1: 122-125.

Rathod, A., Vaidya, M., \& Ali, S. (2018). Genetic studies of productive and reproductive attributes of Surti buffalo in Maharashtra. International Journal of Livestock Research 8(8): 309-314.

Rosati, A., Van Vleck, L. D. (2002). Estimation of genetic parameters for milk, fat, protein and mozzarella cheese production for theltalian river buffalo Bubalus bubalis population. Livestock Production Science 74:185-190.

Soysal, M. I., Guven, H., Gurcan, E. S., \& Genc, S. (2015). The Estimation of lactation milk record with partial milk record in Anatolian water buffalo. 8th Asian Buffalo Congress, p.67, April 21-25, Istanbul-Turkey.

Soysal, M. İ., Genç, S., Aksel, M., Özkan Ünal, E., \& Gürcan, E. K. (2018). Effect of Environmental Factors on Lactation Milk Yield, Lactation Length and Calving Interval of Anatolian Buffalo in Istanbul. Journal of Animal Science and Products 1 (1):93-101.

Şahin, A., \& Ulutaş, Z. (2014). Some environmental factors effect on milk yield estimated with different methods in Anatolian buffaloes. Journal of the Faculty of Veterinary Medicine Kafkas University 20(1):79-85.

Şekerden, Ö. (2011). Factors Affecting Somatic Cell Counts and Their Relations with Milk and Milk Constituent Yield in Anatolian and F1 Anatolian x Italian Crossbred Buffaloes. Animal Production 52 (1): 9-16.

Tekerli, M., Küçükkebabçı, M., Akalın, N. H., \& Koçak, S. (2001). Effects of environmental factors on some milk production traits, persistency and calving interval of Anatolian buffaloes. Livestock Production Science 68: 275-281. 
Tekerli, M., Altuntaş, A., Birdane, F., Sarımehmetoğlu, O., Doğan, i.., Bozkurt, Z., Erdoğan, M., Çelik, A., Koçak, S., Gürler, Z., Bülbül, T., Kabu, M., Çelikeloğlu, K. (2016). Comparative Determination of Improvement Opportunities for Production Traits, Body Measurement and Protein Polimorphism in a Herd Consisting of Anatolian Buffaloes from Different Regions: Lactation Traits and Genetic Polimorphism. Lalahan Hayvancılık Araştırma Enstitüsü Dergisi 56 (1):7-12.

Tekerli, M. (2019). Buffalo Star data records, account and project tracking program, v5.04. Afyon Kocatepe University, Afyon karahisar, Turkey http://88.249.41.173:83/iletisim.aspx
TUIK. (2020a). Turkish Statistical Institute Statistics. Available in http://www.turkstat.gov.tr/Start.do, Accessed on: $15 \mathrm{Apr}$, 2020

TUIK. (2020b). Turkish Statistical Institute Statistics. Available in: http://tuik.gov.tr/PreTablo.do?alt_id=1002, Accessed on: 15 Apr, 2020

Uğurlu, M., Kaya, İ., \& Saray, M. (2016). Effects of some environmental factors on calf birth weight and milk yield of Anatolian Water Buffalo (Bubalus Bubalis). Bulgarian Journal of Agricultural Science 22 (6): 995-998. 